Elżbieta Dubas

Uniwersytet Łódzki

\title{
Starość znana i nieznana - wybrane refleksje nad współczesną starością
}

\author{
Old age known and unknown - chosen reflections on \\ contemporary old age
}

Streszczenie. W tekście autorka podejmuje refleksje nad stanem wiedzy naukowej i społecznej świadomości na temat procesu starzenia się i starości. Szczególnie zwraca uwagę na te zagadnienia, które ukazywane są w sposób niepełny i które powinny być przedmiotem dalszych badań i analiz naukowych. Zalicza do nich fragmentaryczną wiedzę o cielesności, psychiczności i duchowości człowieka starszego, trudne tematy egzystencjalne, m.in. doświadczenie śmierci i osamotnienia, zagadnienia wymagające „weryfikacji”, np. kult młodości i zewnętrzności, potrzeby osób starszych, opieka i pomoc w starości, rola rodziny, odniesienie do rozwoju i aktywności, zmiany i pośpiechu, przewidywalność i przygotowanie do starości, a także tzw. gerontologiczne tabu: zaprzeczanie starości i duchowości, odsuwanie kwestii przemijania i transcendencji, towarzyszenie w drodze człowiekowi starszemu. Ukazuje potrzebę traktowania starości jako wartości.

Słowa kluczowe: starość, refleksje, niedostatek wiedzy o starości, wartość starości

Summary. In the text the authoress has reflections on the state of scientific knowledge and social awareness of the topic of ageing process and old age. She particularly pays attention to the issues which are shown in an incomplete way and which should be the subject of further scientific studies and analyses. They include fragmentary knowledge of corporeality, mentality and spirituality of an elderly person, difficult existential topics, among them the experience of death and loneliness, issues requiring "verification", e.g. the cult of youth and outsideness, the needs of the elderly, care and help in old age, the role of a family, the attitude to development and activity, change and hurry, predictability and preparing for old age and also the so called gerontological taboo: denying old age and spirituality, pushing away the question of passing and transcendentalism, accompanying an elderly person in their journey. She shows the need of treating old age as value.

Keywords: old age, reflections, inadequate knowledge about old age, the value of old age 


\section{6 | Elżbieta Dubas}

\section{Wstęp}

Starość i proces starzenia się niewątpliwie należą już do relatywnie bardzo dobrze rozpoznanych zjawisk opisujących ten złożony fenomen ludzkiego życia. Świadczy o tym bogate piśmiennictwo, referujące liczne i wieloaspektowe badania empiryczne, realizowane w kraju, jak i za granicą, a także teoretyczny namysł nad starzeniem się, jak na razie, jednak podejmowany głównie w literaturze obcej. Można stwierdzić, że o starości i starzeniu się wiemy już bardzo wiele, szczególnie gdy zasobność tej wiedzy porównamy z wiedzą o innych etapach życia ludzkiego, a w szczególności młodością, a także dzieciństwem i dorosłością. Wiedzę tę wykorzystujemy w profilaktyce i terapii gerontologicznej. W mniejszym stopniu natomiast uwzględniana jest ona w polityce państwa i działaniach centralnie sterowanych na poziomie krajowym i regionalnym, choć i to stopniowo się zmienia. Przedmiotem tego artykułu jest jednak głównie refleksja skoncentrowana wokół pytania: Czego o starości jeszcze nie wiemy? Tekst ma charakter refleksji nad stanem niewiedzy gerontologicznej, nad stanem jej pewnych i zarazem istotnych braków, a także wątpliwości, których usunięcie być może przyczyniłoby się do funkcjonowania człowieka w wieku starszym w sposób bardziej pomyślny. Zanim jednak zostaną podjęte refleksje nad „nieznaną” starością, kilka informacji o starości znanej.

\section{Starość znana}

Rozpoznanie starości dotyczy wielu jej ogólnych i szczegółowych aspektów, które jednak najogólniej koncentrują się wokół trzech, najczęściej wymienianych jako zakresy starzenia się. Są nimi aspekt biologiczny, psychiczny i społeczny starzenia się. Starość została rozpoznana przez nauki biologiczne i medyczne, nauki o życiu i zdrowiu człowieka, a także przez nauki społeczne, w tym przez psychologię i socjologię, a także przez pedagogikę, a w szczególności andragogikę i geragogikę, jak również, choć w mniejszym zakresie, przez nauki humanistyczne, w szczególności filozofię i teologię. Niewątpliwie tak szeroką perspektywę badawczą, ciągłość i systematyczność badań gerontologicznych, w Polsce począwszy od lat siedemdziesiątych $\mathrm{XX}$ wieku, można wiązać $\mathrm{z}$ wyodrębnieniem dyscypliny naukowej jaką jest gerontologia (w latach dwudziestych XX wieku) oraz z konsekwencją jej uprawiania przez przedstawicieli różnych dyscyplin naukowych. Niewątpliwie także działalność Polskiego Towarzystwa Gerontologicznego, realizowa- 
na od 1972 roku, scalała wysiłki naukowe badaczy skoncentrowanych wokół tematu starości i starzenia się ${ }^{1}$.

Warto wskazać na duże szeroko zakresowe ogólnokrajowe badania diagnozujące polską starość. Zostały one zapoczątkowane przez Jerzego Piotrowskiego $(1973,1975)$ w latach siedemdziesiątych XX wieku, powtórzone w latach 1999-2001 pod kierunkiem Brunona Synaka (2002), a ostania ich odsłona to wyniki badań, opublikowane w 2012 roku, w ramach projektu PolSenior, zrealizowanego pod kierunkiem Piotra Błędowskiego (Mosakowska, Więcek, Błędowski, 2012). Główne zakresy tematyczne tych badań dotyczą: sytuacji zdrowotnej i sprawności osób starszych, opieki i pomocy w chorobie, sytuacji materialnej, funkcjonowania gospodarstw domowych, sytuacji mieszkaniowej, roli rodziny i aktywności zawodowej osób starszych. Te trzy badania ujawniają również, choć nieco odmiennie, wybrane aspekty z zakresu psychogerontologii. Brakuje w nich, co należy podkreślić z naciskiem, zagadnień związanych z edukacją i duchowością.

W wielu uczelniach wyższych funkcjonują jednostki naukowe (katedry, zakłady), prowadzące badania naukowe w zakresie gerontologii medycznej i społecznej. Także liczne prace dyplomowe - magisterskie i licencjackie, a także prace doktorskie i habilitacyjne podejmowały problematykę gerontologiczną.

Gerontolodzy polscy włączyli się także w realizację licznych projektów badawczych - krajowych oraz finansowanych ze środków Unii Europejskiej. Należy też odnotować ukazanie się na polskim rynku wydawniczym kilku ważnych publikacji z zakresu gerontologii o charakterze encyklopedyczno słownikowym (Borsowa (red.) 1986; Zych, 2001; Zych 2007). Do tego należy dodać bardzo intensywny rozwój UTW, wykorzystujących wiedzę gerontologiczną i realizujących także badania w tym zakresie ${ }^{2}$, oraz skutecznie zagospodarowujących część społecznej przestrzeni pomyślnym starzeniem się w praktyce.

1 Polskie Towarzystwo Gerontologiczne aktualnie kierowane przez prof. dr hab. med. Katarzynę Wieczorowską-Tobis, skupia członków w dwóch sekcjach: medycznej i społecznej, swój ostatni - XII Zjazd, odbywało w Poznaniu w roku 2013, konsekwentnie, poprzez konferencje, wydawnictwo, informacje, kieruje w Polsce pracami badawczymi w zakresie gerontologii.

2 Liczba UTW w Polsce to 450 takich placówek według wypowiedzi Rzecznika Praw Obywatelskich w I programie PR z dnia 16.09.2013 roku. 


\section{8 | Elżbieta Dubas}

\section{Starość jako wciąż nieznany etap życia człowieka}

Mimo niewątpliwie znaczącej już wiedzy gerontologicznej, jaką dysponują gerontolodzy, w tym także i polscy, starość wydaje się być wciąż etapem życia nieznanym, a przynajmniej nie rozpoznanym w sposób satysfakcjonujący, czyli taki, który zapewniłby kierowanie procesami starzenia się w sposób pomyślny dla poszczególnych jednostek, a także całych społeczności. Starość jako niezwykle złożony fenomen ludzkiej egzystencji, wymyka się bowiem precyzyjnemu poznaniu. Wiele jej zakresów jest trudno dostrzegalnych i wiele też jest pokrywanych milczeniem, kamuflowanych, stereotypizowanych, a nawet tabuizowanych. Przedmiotem tego fragmentu tekstu jest przede wszystkim refleksja skoncentrowana wokół pytań: Czego jeszcze nie wiemy o starości? Co wiemy o niej w sposób powierzchowny i niedokładny? Czego nie chcemy wiedzieć o starości i dlaczego?

a) Niepełna wiedza o starości

Rozpoznanie starości wciąż jest w pewnym stopniu fragmentaryczne. Badanie starości i procesów starzenia się, zasadzone na pierwotnym i wciąż dominującym podejściu badawczym, wyjaśniającym starość i starzenie się poprzez obserwowalną zewnętrznie aktywność osoby starszej, tak określonej ze względu na wiek kalendarzowy, dostarcza wiedzy stosunkowo powierzchownej i jednostronnej. Analizy ilościowe, choć niewątpliwie ważne, pomijają rozpoznanie istotnych wewnętrznych mechanizmów „opisujących” starość, a także nie dotyczą duchowości człowieka, zmieniającej się na przestrzeni jego życia, również warunkowanej cywilizacyjnie, kulturowo i społecznie. Można przyjąć, że pełniejsze rozpoznanie starości możliwe będzie przez uwzględnienie i scalenie trzech wymiarów funkcjonowania człowieka: cielesności (ciała soma), psychiczności (psychiki psyche) i duchowości (ducha spirit). Starość, jeszcze bardziej niż początki życia, wymaga pełniejszego rozpoznania właśnie w aspekcie tak pomyślanej trójjedni. Warto zaakcentować te jej zakresy, które wymagają dopowiedzenia i przeformowania.

Cielesność człowieka starszego wyraża najogólniej stosunek do własnego ciała, najlepiej gdy uwewnętrzniony przez samą osobę starszą, a nie jedynie jej zewnętrznie narzucony. Cielesność to w indywidualny sposób zdefiniowane znaczenie własnego ciała oraz zgodne $z$ tym posługiwanie się nim w procesie życia i starzenia się. W tym okresie istotnie nasila się już konieczność dbałości o sprawność fizyczną organizmu, m.in. poprzez właściwe odżywianie, higienę i aktywność ruchową (Nowocień, Zuchora (red.) 2012). Cielesność człowieka starszego zawiera również postawę wobec zabiegów pielęgnacyjno-opiekuńczych nad jego ciałem, wypracowywaną przez życie. 
To bardzo ważne w starości - chcieć i umieć pielęgnować własne ciało i/lub zgadzać się na takie zabiegi ze strony innych. Cielesność zawiera również poczucie własnej intymności, odmiennie doświadczane w przypadku każdej osoby. Cielesność starości to także pytanie o możliwość rzeczywistej transcendencji własnego starzejącego się ciała ${ }^{3}$, tym bardziej skomplikowanej i zaburzanej, gdyż utrudnianej przez narzucane mody, dotyczące wyglądu zewnętrznego, odrzucające i kamuflujące zewnętrzne oznaki starzenia się, zaprzeczające biologicznemu starzeniu się człowieka. Cielesność starości to konieczne połączenie jej wymiaru materialnego $\mathrm{z}$ duchowym, bo źle jest, gdy cielesność charakteryzuje jedynie wymiar materialny (I. Weinbach, 1986, cyt. za Dubas 2000, s. 108). Można stwierdzić, że rozpoznanie i uwewnętrznienie wartości jaką jest własne ciało pozwala „dobrze się w nim poczuć", a to niewątpliwie stanowi istotny element pomyślnej starości. W obszarze cielesności mieści się ważne zadanie rozwojowe starości, o którym pisał E. Erikson (E. Erikson, R. Havighurst, 1970, cyt. za Pietrasiński 1988, s. 385-391) - przystosowanie do rosnących ograniczeń fizycznych. W kontekście powyższych rozważań można je rozszerzyć i ująć jako ukształtowanie dojrzałej postawy wobec własnego starzejącego się ciała.

Psychiczność człowieka starszego zawiera istotne procesy autoidentyfikacji. Liczne czynniki przez całe życie kształtowały samoocenę bycia osobą, również osobą starszą. Procesy autoidentyfikacyjne dopełniały tożsamość jednostki, czyniąc ją coraz bardziej spójną, zintegrowaną. Psychiczna strona starości to również psychiczne uwarunkowania jakości życia, poczucia życiowej satysfakcji, poczucia szczęścia, poczucia bycia autorytetem lub osobą marginalizowaną, poczucie bycia bądź nie autorem swego życia itp. Znaczącymi są więc wśród nich czynniki motywacyjne, skłaniające do przyjęcia pozytywnej postawy wobec starości, podnoszące samoocenę i poczucie sprawstwa ${ }^{4}$. W obszarze psychiczności mieści się także wciąż nierozstrzygnięte przez badaczy psychologów pytanie o stałość i zmienność psychicznych „składników” osobowości człowieka (McCrae, Costa Jr. 2005, rozdz. 7 i inne) oraz jak owa stałość i zmienność określają ludzką pomyślną starość. Ważnym jest w dalszym ciągu odkrywanie i wyjaśnianie mechanizmów psychicznych, motywujących do zmiany, do radzenia sobie w nowych i trudnych sytuacjach życiowych wynikających ze starości. Bowiem, jak pisze Anna Brzezińska, „czas starości to czas wielkich zmian” (Brzezińska 2005, s. 610),

3 Transcendencja ciała jako jeden z wymiarów gerotranscendencji ( por. L. Tornstam, cyt. za J. Halicki 2004, s. 272.

4 Por. koncepcja pozytywnego starzenia się: R. D. Hill 2009. 
a postawa wobec zmiany, także w starości, staje się współcześnie jedną z kluczowych postaw życiowych człowieka. Niemałą rolę w procesie jej kształtowania odgrywa proces socjalizacji i całożyciowej edukacji.

Duchowość jest niewątpliwie decydującym, choć najsłabiej akcentowanym w badaniach gerontologicznych obszarem doświadczania starości. Doświadczenie starości jest przede wszystkim doświadczeniem duchowym, mimo że, paradoksalnie, starość wydaje się być zdominowana przez cielesność. Z perspektywy duchowości można odczytać starość jako „kluczowy etap w osiąganiu pełni człowieczeństwa" (Dubas 2004, s. 142-144). To przez duchowość starość się rozwija i pełniej manifestuje. Starości potrzebna jest duchowość; bez duchowości starość jest niezrozumiała i niemożliwa do zaakceptowania. Jest jedynie pasmem udręk i ubytków, których sensu nie można odnaleźć. W starości „zawiera się” wiele doświadczeń egzystencjalnych, związanych z przeżywaniem choroby, cierpienia, niepełnosprawności, śmierci innych i własnej. Starość bywa ogólnie określana jako kryzys (Szatur-Jaworska, Błędowski, Dzięgielewska, 2006, rozdz. 3) ${ }^{5}$, ponieważ kumuluje się w niej wiele kryzysowych doświadczeń. Odniesienie do nich wymaga dojrzałości duchowej. Starość dotyka też bolesnej samotności. Konteksty sensu życia, celu i wartości życiowych wręcz nabrzmiewają w okresie starości. Starość włącza się w „filozofię” życia człowieka, a doświadczanie starości może wskazywać na posiadanie bądź nie sztuki starzenia się, będącej oczekiwanym składnikiem sztuki życia (Dubas, 2012, s. 17 i dalsze). Duchowość człowieka (starszego) niewątpliwie należy rozpoznawać, by dzięki tej wiedzy skuteczniej wspierać go w jego drodze rozwojowej.

b) Trudne tematy egzystencjalne

Odnosząc się do powyższych rozważań, niewątpliwie należy uwypuklić zagadnienia szczególnie trudne dla naukowego rozpoznania, a i zarazem, szczególnie trudne w indywidualnym doświadczaniu. Do takich zagadnień trzeba zaliczyć:

- doświadczenie starzenia się - to przykra świadomość starzejącego się ciała, słabnących funkcji psychicznych, starzenia się ducha, przy czym to duchowa starość decyduje o poczuciu bycia starym. Do tego należy dodać jeszcze poczucie zmęczenia życiem, przesyt doświadczeniem życiowym, poczucie straty w odniesieniu do mijających bezpowrotnie lat, młodości i urody;

5 Por. kryzysy starości : B. Szatur-Jaworska, P. Błędowski, M. Dzięgielewska, 2006, rozdz. 3. 
- doświadczanie bólu i cierpienia, tak fizycznego jak i psychicznego, w sytuacji choroby, kalectwa, samotności i w innych trudnych sytuacjach, jakie dzieją się w starości;

- doświadczenie śmierci - innych osób i własnej, doświadczanie procesu przemijania i umierania jako zmierzania do kresu swojego życia, związane z silnym lękiem przed nieznanym i nicością;

- doświadczenie osamotnienia - najczęściej dokuczliwego w kontekście braku głębokich więzi psychicznych z najbliższymi, braku zrozumienia i bycia odsuniętym na margines życia społecznego, nasilającej się niesamodzielności oraz ubożenia świata wewnętrznego, a także bardzo często w kontekście tej ostatecznej samotności, jaką stwarza perspektywa bliskiej śmierci. Osamotnienie to swoista plaga współczesności, jednak najsilniej dotyka ona tych najbardziej bezbronnych - dzieci i osoby starsze. Można mówić o specyficznej odmianie samotności jaką jest właśnie samotność starości (Dubas 2000, s. 123);

- doświadczenie intymności. Intymność starości zawiera wiele wymiarów związanych z procesem starzeniem się, ale i również z poczuciem własnej intymności ukształtowanym w ciągu trwania całego życia, a odnoszącym się m.in. do własnego ciała i codziennych rytuałów. Intymność starszych pokoleń różni się od intymności ludzi młodszych. Intymność coraz częściej pozbawiana jest jej podstawowego duchowo-osobistego wymiaru. Człowiek starszy często ograbiany jest ze swej intymności w instytucjach zdrowia i opieki. Tym samym pozbawiany jest najgłębszej cząstki samego siebie, swej podmiotowości, godności i osobistej tajemnicy.

Wszystkim tym doświadczeniom często towarzyszą pytania o sens, wartości i cel życia, w doświadczeniu indywidualnym i w perspektywie uniwersalnej.

c) „tematy” do weryfikacji

Uogólniając można stwierdzić, że starość w nowoczesności to starość silnie uwarunkowana kontekstem społeczno-kulturowym, który dość wyraźnie próbuje „odciąć się” od biologicznych podstaw życia ludzkiego. Starość w ponowoczesności natomiast to starość ograbiana z sensu. Łącznie daje to obraz starości, która wymaga działań weryfikujących.

Oczywistym jest, że starość zawsze była silnie warunkowana kontekstem społeczno-kulturowym. Jak silnie jednak kontekst ten ułatwia lub utrudnia indywidualne doświadczanie starości - to ważne pytanie dla współczesnego gerontologa - badacza i praktyka. Zwracając uwagę na współczes- 


\section{2 | Elżbieta Dubas}

ne społeczno-kulturowe uwarunkowania starości, warto uwypuklić niektóre niekorzystne zjawiska, silnie oddziaływujące na ludzką starość i deformujące starość. Ich obecność w społeczeństwie i kulturze jako określone koncepcje, tendencje, mody, style życia, nie pozostaje bez wpływu na indywidualne losy osób starszych. Należy zwrócić szczególną uwagę na niektóre z nich, gdyż silnie wykluczają one osoby starsze z życia społecznego albo utrudniają pomyślne starzenie się. Niektóre z nich też funkcjonują jako mity ${ }^{6}$, budujące określone stereotypowe spostrzeganie starości, a wiec nie zawsze zgodne z rzeczywistym obrazem starości, a te obrazy, jak wynika z badań Jerzego Halickiego (2010) ${ }^{7}$, bywają liczne i zindywidualizowane.

Kult młodości. Niewątpliwie silnie uwypuklony w społeczeństwach otwartych, pluralistycznych, stawiających na cechy młodości, które stanowią zarazem istotny fundament tych społeczeństw. Należy do nich młodzieńczy wigor, sprawność fizyczna, zdolność do rywalizacji, konkurencyjność, nastawienie na rozwój, szybkość reakcji na zmianę. Kult młodości wzmocnił także znaczenie kultury prefiguratywnej (Mead, 2000), pozbawiając osoby starsze autorytetu i roli edukacyjnej. Pewną, choć budząca kontrowersję, próbą poradzenia sobie $z$ takim wykluczeniem, jest zjawisko kidult. Opisane w latach dziewięćdziesiątych XX wieku w USA, wskazuje na to, że by sprostać obsesji kultu młodości, pewna część ludzi dorosłych (starych) nie chce nigdy dorosnąć, chcą w tej młodości uczestniczyć stale, m.in. poprzez konsumpcję charakterystyczną dla dzieci i młodzieży (poprzez ubiór, uczesanie, gadżety, słuchaną muzykę, zabawki typowe dla młodszych pokoleń), poprzez udział w sportach ekstremalnych, poprzez zachowania seksualne potwierdzające wieczną młodość (Twardowska-Rajewska 2006, s. 138-142). Kidult jednak zatrzymuje rozwój człowieka na pewnym etapie, nie pozwala na podejmowanie kolejnych zadań rozwojowych, utrudnia osiąganie pełnej zharmonizowanej tożsamości.

Kult ciała. Oznacza, w przypadku człowieka starszego, ograniczone spostrzeganie starości, gdyż jedynie przez pryzmat wymiaru cielesnego, przy czym cielesność rozumiana jest tutaj jednostronnie, powierzchownie. Troska o własne ciało, o ładny wygląd, zgrabną sylwetkę, atrakcyjność fizycz-

6 Joanna Staręga-Piasek wymienia 6 takich mitów: 1. Ludzie starzy są najuboższą kategorią społeczną, 2. Ludzie starzy są obciążeniem dla społeczeństwa i dla budżetu państwa, 3. Rząd nie prowadzi polityki społecznej wobec ludzi starych, 4. Wraz z osiągnięciem wieku emerytalnego powstaje obowiązek przejścia na emeryturę, 5. Ludzie starzy to nie tylko podatna na wykluczenie, ale i wykluczona kategoria społeczna, 6. Starość jest pełnym negatywów okresem w życiu człowieka ( J. Staręga-Piasek 2006, s. 128 i dalsze).

Jerzy Halicki diagnozuje 14 różnych obrazów starości ( J. Halicki 2010). 
ną przesłania rozwój innych potrzeb, wyzwala wręcz obsesyjną koncentrację na ciele kosztem rozwoju własnych potencjałów psychicznych i duchowych. Kult ciała więc, podobnie jak i kult młodości, udaremnia wieloaspektowy rozwój człowieka i pełne urzeczywistnienie siebie, także w głębokich relacjach interpersonalnych.

Kult zewnętrzności. Człowiek starszy, w kulturze powierzchowności, to przede wszystkim konsument dóbr materialnych i beneficjent różnorodnych usług. To posiadacz dóbr materialnych, które stanowią o jego wartości. Zewnętrzność wypiera więc z życia doświadczenie jego głębi. Zwyczajne ludzkie marzenia, takie jak np. marzenie o szczęściu rodzinnym, o bezinteresownej przyjaźni, o byciu kochanym bezwarunkowo, są wypierane, a własne prawdziwe oblicze ukrywane jest za rożnymi fasadami, np. osoby bogatej, podróżującej każdego roku do odległych krajów, często zmieniającej samochody itp. Zewnętrzność utrudnia rozwój osoby „w głąb” i często rodzi osamotnienie.

„Nowoczesność” starości. To swoisty przymus nadążania za zmianami cywilizacyjnymi, propozycjami stylów życia lansowanymi przez media masowe, osiągnięciami nowoczesnych technologii informatycznych. Należy zauważyć, że człowiek starszy w Sieci to często człowiek bez głębokich relacji z Innymi i bardzo osamotniony. Starość nie może opierać się jedynie na tym, co nowoczesne i nie może gonić za nowoczesnością. Starość bowiem „zaprogramowana” jest raczej na to, by integrować wartości tradycyjne z nowoczesnymi i kłaść pomost między starym i nowym.

Medycyna panaceum na starość. Wydłużanie życia ludzkiego ${ }^{8}$, bardzo skuteczna pomoc w trudnych schorzeniach geriatrycznych i chorobach zagrażających życiu, a także w niedoskonałościach obniżających satysfakcję życiową, sprawiają wrażenie, że człowiek „wygrał” ze starością. Jest to jednak tylko wrażenie. Długie życie często nie jest życiem satysfakcjonującym ani samego człowieka starszego, ani jego najbliższych, ani też szerszego społeczeństwa. Wręcz spektakularne osiągnięcia medycyny w walce z chorobami i niepełnosprawnością należy bowiem skuteczniej zespolić z działaniami wspierającymi jakość życia człowieka w późnym wieku. Jakość życia bowiem to swoisty, wciąż aktualny gerontologiczny evergreen.

Potrzeby osób starszych. Diagnoza społeczna często nie odzwierciedla rzeczywistych potrzeb człowieka starszego, lecz potrzeby wylansowane przez decydentów. Ujawnia ona wynik uśrednionych badań statystycznych,

8 Średnie trwanie życia ludzkiego Polsce na rok 2012 wynosiło dla kobiet - 80,98 lat, dla mężczyzn - 72,71 (dane Głównego Urzędu Statystycznego). 


\section{4 | Elżbieta Dubas}

a także bywa projekcją oczekiwań społecznych i naukowych. Jakie są rzeczywiste potrzeby poszczególnych osób starszych ? - oto kluczowe pytanie badawcze. Wbrew pozorom stan wiedzy w tym zakresie nie jest satysfakcjonujący. Warto też w tym względzie mieć na uwadze trudność empirycznego badania potrzeb osób starszych. Inną kwestią, choć z związaną z powyższą, są potrzeby edukacyjne osób starszych. Należą one do stosunkowo słabo, bo w wąskim (szkolnym) zakresie, rozpoznanych zakresów starzenia się. $\mathrm{Na}$ dal aktualne są pytania: Jakiej edukacji potrzebuje człowiek starszy? Czego rzeczywiście chciałby się uczyć? Jakie ma możliwości w zakresie uczenia się? Czy UTW odpowiadają tym możliwościom i oczekiwaniom? Oprócz bowiem potrzeby poszerzania, uzupełniania i uaktualniania wiedzy praktycznej oraz rozwijania zainteresowań, szczególnie znaczące są potrzeby uczenia się w sytuacji zmiany i w sytuacjach trudnych.

Opieka i pomoc w starości. Staje się coraz częściej domeną wyspecjalizowanych instytucji. Ich profesjonalizm jednak często nie obejmuje intymności relacji. Instytucje totalne, takie jak domy pomocy społecznej, mają utrudnioną możliwość zaspokajania wewnętrznych potrzeb ich mieszkańców. Ich daleko idąca ingerencja w intymny świat człowieka starszego ograbia go z podmiotowości i godności osobistej. Jakiej opieki i pomocy rzeczywiście potrzebuje człowiek starszy i jak można ją zagwarantować? Jakiej pomocy potrzebuje szczególnie w odniesieniu np. do wstydliwych obszarów własnego starzenia się? To kolejne obszary badań gerontologicznych, których wyniki powinny posłużyć dobrym rozwiązaniom praktycznym. Należy też zwrócić uwagę na wzmocnienie rodziny w jej funkcjach opiekuńczych i pomocowych wobec swoich starszych członków, jak również na wsparcie grup samopomocowych, działających w zakresie opieki i pomocy.

Rodzina to naturalne i oczekiwane środowisko życia ludzi. Starość coraz częściej jest jednak przeżywana poza rodziną - jest starością samotną lub w instytucji. Problem rodziny jest jednym z głównych problemów życia człowieka starszego. Utrata autorytetu i marginalizacja osób starszych w rodzinie, odrzucanie tradycyjnych wartości i przekazu międzypokoleniowego, powierzchowność relacji rodzinnych, brak czasu dla wspólnotowego życia, egocentryczne postawy poszczególnych członków rodziny, tendencje indywidualizacyjne, mała liczebność rodzin, coraz częstsza bezdzietność

9 Badanie potrzeb edukacyjnych osób starszych w następujących wymiarach: życia rodzinnego, życia codziennego, zawodowego, towarzysko-koleżeńskiego, egzystencjalno-religijnego, społeczno-obywatelskiego, intelektualnego, estetycznego, kultury fizycznej i zdrowotnej, w zakresie kształtowania charakteru, w zakresie kontaktu z przyrodą (Dubas 1990, s. 212; E. Dubas ). 
małżonków, częste jedynactwo i brak rodzeństwa, życie w oddaleniu przestrzennym, trudności materialne w rodzinie, także jako pochodne transformacji ustrojowej niewątpliwie tworzą niekorzystne tło dla życia rodzinnego. Ubożenie i powierzchowność rodzinnych więzi skazuje osoby starsze na relacje z instytucjami, które są dla nich zaskakujące i trudne, gdyż dotychczasowy przebieg ich życia nie przewidywał takiego scenariusza. Należy podkreślić, jak ważną i nie do przecenienia jest rola małżonka w starości. Należy uwypuklić znaczenie małżeństwa z długoletnim stażem, jako skutecznego wsparcia w chorobie i w innych trudnościach, ze względu na gruntowną znajomość własnych potrzeb, wzajemną bliskość i przywiązanie. W starości bowiem, w sposób wyrazisty, potwierdza się teza, że człowiek jest istotą przywiązania.

Rozwój. Nastawienie na permanentny rozwój to swoiste wyzwanie współczesności. Rozwój to w pewnym stopniu atrybut współczesnego człowieka. Rozwój to jednak „przeceniona” wartość życia, jeśli nie jest powiązana z innymi wartościami. Rozwój wymaga uniwersalnej aksjologii i odpowiedzi na pytania: Rozwój ku czemu? Po co? Dlaczego? Nie powinno bowiem rozwijać się byle co i byle jak. W starości na taki rozwój po prostu nie ma już czasu. Rozwój w starości powinien zmierzać ku takim celom i wartościom, które nadadzą sens życiu człowieka starszego (Dubas, 2002, s. 15-22).

Zmiana i pośpiech. Nastawienie na zmianę, a przy tym szybką zmianę, to również cecha współczesności. Homo pycnolepticus, według Paula Verilio, to człowiek żyjący szybko i szybkość traktujący jako najwyższą wartość Marek Bieńczyk, cyt. za Aleksander, 2002, s. 411). W tym kontekście rodzi się pytanie: czy człowiek starszy może odpowiedzieć na takie wyzwanie cywilizacji i czy to może służyć jego dobru, tym bardziej że, jak pisze T. Aleksander: „Uczeni straszą nas wizją »homo pyknolepticus«, który (...) pod wpływem nadmiaru podniet traci świadomość (...)"(tamże, s. 415). Odpowiedź jest jednoznaczna. Dlatego homo pycnolepticus nie może być propozycją dla człowieka w wieku starszym, choć niewątpliwie ma on poczucie szybko umykającego czasu i potrzebę, by go nie marnować. Pośpiech cywilizacyjny jednak w sposób zasadniczy pozbawia człowieka u schyłku życia możliwości kontemplowania jego uroku i medytacji nad życiem, z której może wyniknąć zrozumienie życia.

Kryzysy starości. Jak stwierdzono wyżej, starość kumuluje w sobie wiele trudnych wyzwań i tworzy w ten sposób szczególnie kryzysową sytuację rozwojową ( Szatur-Jaworska, Błędowski, Dzięgielewska, 2006, rozdz. 3). Do kryzysów starości Barbara Szatur-Jaworska zalicza: przejście na emeryturę, opuszczenie domu przez ostatnie dziecko, wdowieństwo, przewlekłą, wy- 


\section{6 | Elżbieta Dubas}

wołującą niepełnosprawność chorobę, zmianę miejsca zamieszkania (przenosiny do dzieci lub do instytucji opiekuńczej) (tamże, s. 73). Jednak kryzysy nie tylko obciążają negatywnym doświadczeniem. Mogą one uruchamiać potencjały rozwojowe i sprzyjać osiąganiu nowych wartości w starszym życiu. Warto więc ukazywać kryzys jako sytuację rozwojową, jako źródło uczenia się, przystosowania i zmiany w nowych okolicznościach życiowych. Warto więc zmieniać indywidualne i zbiorowe nastawienie wobec kryzysów życiowych.

Nastawienie na aktywność. Aktywność jest niewątpliwie istotnym czynnikiem afirmacji starości i utrzymania organizmu w sprawności psycho-fizycznej ${ }^{10}$. Jednak nadmierna aktywność, aktywizm, aktywność bez czasu wolnego, aktywność głównie manifestowana zewnętrznie, bez wewnętrznej perspektywy, utrudnia w szczególności wewnętrzny rozwój człowieka starszego, który wspiera jego proces dojrzałego starzenia się. Nakaz bycia koniecznie i zawsze aktywnym to często kamuflaż rzeczywistej trudności -trudności osobistej konfrontacji ze starością. Bywa to także kamuflaż głębokiego osamotnienia (Dubas, 2000).

Przewidywalność starości. W refleksji nad starością nasuwa się także pytanie, czy starość (wszystko, co ona przyniesie, wszystko, co z nią się pojawi) można w jakimś zakresie przewidzieć? Starość, tak jak i całe życie ludzkie, nie jest do przewidzenia. Nie sposób bowiem zaprzeczyć choćby zaskakującej roli przypadku w ludzkiej egzystencji. Choć niewątpliwie należy uznać, że starość, a precyzyjniej - definiowanie poczucia własnego ja u osoby starszej, najogólniej jest kontynuacją nabytych postaw, stylu życia, preferowanych wartości itp. we wcześniejszych etapach życia, co potwierdza teoria ciągłości Roberta Atchley`a, to jednak starość bywa także zaskakująca, gdyż zawiera zdarzenia zachodzące nieoczekiwanie dla człowieka (discontinuity) (R. Atchley, cyt. za Hill, 2009, s. 65, 2, 71).W tym kontekście istotne znaczenie zyskuje rozumienie przygotowania do starości.

Przygotowanie do starości, w powyższym kontekście, jest wiec procesem całego życia, uwzględniającym tak naturalną edukację do starości, w szczególności w rodzinie, jak i edukację instytucjonalną, profesjonalną, w tym szkolną, poczynając od dzieciństwa. Edukacja do starości sprzyja całożyciowemu uczeniu się starości jako nabywaniu postawy wobec starości w ogóle i wobec własnej starości (Dubas, 2012, s. 20-21). Edukacja taka powinna realizować także funkcje egzystencjalne, co pozwoliłoby człowiekowi starsze-

10 Por. czynniki aprobaty starości według Aleksandra Kamińskiego (A. Kamiński 1978, s. 360-364) oraz gerontologiczną teorię aktywności (J. Halicki 2006, s. 261-262). 
mu lepiej radzić sobie z trudnościami procesu starzenia się (Dubas, 2008, s. 60-61). W kontekście nieprzewidywalności starości, ma znaczenie kształtowanie dojrzałej postawy wobec zmian, nagłych wydarzeń oraz sytuacji trudnych.

d) Gerontologiczne tabu

Wiele zakresów doświadczania starości w znacznym stopniu pokrywanych jest milczeniem, usuwanym $\mathrm{z}$ refleksji nad starością, a tym samym $\mathrm{z}$ repertuaru tematów badawczych. Do nich niewątpliwie należy:

Zaprzeczanie starości pojmowane jako eliminowanie starości z życia społecznego i z jednostkowej i społecznej świadomości. „Nie ma starości” to hasło wyziera ze współczesnych mediów. Osoby z długą biografią są przez nie lansowane jako młode i sprawne bez względu na wiek, jako młodzi inaczej, a określone zabiegi i środki mają zatrzymać młodość na zawsze. Zaprzeczanie starości to niewątpliwie wynik dominacji kultury nowoczesnej i ponowoczesnej, faworyzującej młodość w życiu publicznym;

Zaprzeczanie duchowości. Czynnik duchowy „wypychany” jest przez czynnik cielesności i zewnętrzności, a uniwersalna tęsknota człowieka do duchowości zaspokajana jest jej namiastkami, takimi jak np. ezoteryka itp.

Odsuwanie kwestii przemijania jako tematu trudnego i niewygodnego dla ludzi żyjących w zlaicyzowanych społeczeństwach. W zamian propozycja życia tu i teraz, bez próby odniesienia się do innych perspektyw czasowych i przestrzeni uniwersum. Temat śmierci jest nadal tabuizowany z powodu braku możliwych do akceptacji rozwiązań sprzyjających pokonywaniu lęku przed śmiercią. Instytucjonalizacja śmierci w domach pomocy społecznej, w szpitalach to próba usunięcia śmierci z przestrzeni indywidualnej, w której jest ona najbardziej dojmująca i podmiotowa.

Odsuwanie transcendencji jako wyraz sekularyzacji starości. Perspektywa życia po życiu to również temat trudny dla współczesnych laickich społeczeństw. Problem transcendencji pozostawiany jest ewentualnie instytucjom religijnym, które jednak wyraźnie są marginalizowane i pozbawiane autorytetu.

Osamotnienie starości jako jedna z najtrudniejszych sytuacji osamotnienia człowieka na przestrzeni jego całego życia (Dubas, 2000, s. 123 i inne). Osamotnienie to jest silnie związane $z$ osłabieniem więzi $\mathrm{z}$ najbliższymi i nasilaniem się własnej niemożności bycia samodzielnym i radzenia sobie z trudnościami. Bardzo silnie łączy się z lękiem przed śmiercią i stanowi niezwykle trudny kryzys egzystencjalny.

Towarzyszenie $w$ drodze. To niezwykle celne ujęcie relacji z człowiekiem starszym. W geragogice jest podnoszone do głównego wymiaru profesjo- 


\section{8 | Elżbieta Dubas}

nalnego odniesienia wobec człowieka starszego. W pewnym stopniu jest to jednak temat również zawoalowany. Rodzą się tu bowiem liczne i znaczące pytania: czy rzeczywiście towarzyszymy osobie starszej w jej drodze życiowej? Czy może raczej ukierunkowujemy jej potrzeby według naszej wiedzy, możliwości i oczekiwań? Czy wiemy, jaki jest cel jej wędrówki życiowej i czy umiemy jej w tej wędrówce pomóc? Czy znamy więc proces starzenia się, także ten patologiczny i niepomyślny oraz indywidualne doświadczenie biograficzne starszych osób, którym mamy towarzyszyć w drodze?

\section{Starość jako wartość}

Starość to niewątpliwie coraz dłuższy etap życia człowieka. Można umownie powiedzieć, w kontekście wydłużającego się średniego trwania życia ludzkiego, że to kolejna, trzecia już trzydziestka w biegu życia, dotycząca coraz liczniejszej populacji. Dzieląc schematycznie życie ludzkie na okresy trzydziestoletnie, pierwszy okres od urodzenia do 30 roku życia to okres stawania się człowiekiem dorosłym, obejmujący dzieciństwo i młodość, a także wczesną dorosłość, z okresem moratorium rozwojowego. Pierwsza trzydziestka życia to okres zyskiwania, poprzez procesy socjalizacji i edukacji, kompetencji przydatnych do prowadzenia dorosłego życia. To także czas przedprodukcyjny, przysposabiający do pełnienia roli zawodowej w przyszłości. Druga trzydziestka natomiast (umownie od 30 r. ż. do przejścia na emeryturę), to okres pełnej dorosłości, oznaczający realizację ról i zadań typowych dla człowieka dorosłego, wyznaczonych przez społeczeństwo, to także okres samodzielności i odpowiedzialności oraz realizacji własnych potrzeb i oczekiwań. To wiek produkcyjny, gdyż człowiek realizuje swoje zadania zawodowe i jest obecny na rynku pracy. I wreszcie trzecia trzydziestka (lata 60-te do 90-tych.), to okres starości, zwany też późną dorosłością jako okres poprodukcyjny czas życia na emeryturze, a także czas rozwoju zainteresowań i zmierzania się $\mathrm{z}$ nasilającym się procesem starzenia się. To czas domykania się cyklu życiowego i dopełniania się tożsamości. Trzecia trzydziestka życia zaczyna dotyczyć coraz liczebniejszej populacji. Kolejna zaś, czwarta trzydziestka, także możliwa, to okres długowieczności, który jak na razie, dotyczy tylko wybrańców.

Czy długie życie jest dziś wartością? Warto przypomnieć, że w 1986 roku odbył się w Łodzi V Zjazd PTG, pod hasłem: Długie życie jako wartość. Uczestnicy Zjazdu wówczas nie mieli wątpliwości, że długie życie jest wartością, że warto długo żyć. Jak jest dziś? 
Dziś, w odpowiedzi na to pytanie, pojawia się pytanie dodatkowe: jakie życie warte jest życia? a także inne: czy dziś łatwo jest żyć człowiekowi starszemu? Długie życie, wydaje się, nie jest już wartością samą w sobie, lecz odnoszone jest najczęściej do wskaźników jakości życia. Dla współczesnego człowieka, wydaje się, że długie życie jest wartością wtedy, gdy wiąże się $\mathrm{z}$ jego wysoką jakością.

Obok pozytywnych, dostrzega się także negatywne aspekty życia w starości. Te ostatnie nasilają się wraz z wydłużaniem się życia człowieka. Pozytywne aspekty współczesnej starości to: powszechne zabezpieczenie emerytalne lub rentowe, lepsze warunki socjalne, lepsze warunki higieniczno-zdrowotne, korzystniejsza sytuacja kulturalno-edukacyjna i wyższy poziom wykształcenia, dostępność mediów masowych, powszechne uznanie praw człowieka i człowieka starszego, wyższy stopień samoświadomości i podmiotowości, większa mobilność. Do negatywnych zaś cech współczesnego życia człowieka w starości można zaliczyć: niekorzystne przemiany rodziny (rodzina mała, jedynactwo lub bezdzietność, rozwody, brak psychicznych więzi, oddalenie przestrzenne i inne), zanik bliskich więzi międzyludzkich, panowanie kultu młodości, pozbawianie ludzi starszych autorytetu, negatywne stereotypy starości (ageizm), sekularyzacja życia społecznego, stąd tabu śmierci i przemijania, trudności z radzeniem sobie $z$ cierpieniem i chorobą, kłopoty z zagospodarowaniem czasu wydłużającego się życia, narastająca z wiekiem niesprawność fizyczna i psychiczna, ograniczająca samodzielność czy wreszcie niewydolność państwa w zakresie opieki i leczenia osób starszych i inne.

Starość, by była wartością, wymaga spełnienia kilku istotnych warunków: ukształtowania dojrzałej postawy wobec życia (w tym określenie celu i sensu życia oraz wiodących wartości życiowych); ukształtowania dojrzałej postawy wobec starości, w tym postawy wobec zmiany; dbałości o zdrowie, sprawność fizyczną i psychiczną; bycia aktywnym (w rożnych wymiarach); realizacji własnych potrzeb i zainteresowań oraz pasji; dbałości o relacje interpersonalne i podejmowania działań prospołecznych. Dla wielu warunki te są wciąż co najwyżej znaczącym wyzwaniem.

\section{Próba zakończenia}

Niewątpliwie niełatwo jest posumować powyższe rozważania. W rzeczywistości nie chodzi tu przecież o podsumowania, a raczej próbę zatrzymania się nad wskazanymi refleksjami i wnioskami, jakie mogą z tych refleksji wy- 
nikać. A wszystko po to, być może lepiej zrozumieć starość i lepiej ją przeżywać (z perspektywy jednostkowej), a także skuteczniej wspierać jej przebieg (z perspektywy społeczno-globalnej).

Starość jest przede wszystkim złożonym jednostkowym doświadczeniem egzystencjalnym. Zgłębiając to doświadczenie, pełniej przeżywamy starość, gdyż lepiej ją rozumiemy. Staje się ona wtedy dla nas bardziej szansą rozwoju niż jedynie obciążeniem. Starość więc to nie tylko dożywanie życia, ale jego świadome i autokreacyjne przeżywanie (doświadczanie).

Rozumienie starości to przede wszystkim stopniowe rozumienie siebie samego jako osoby również starzejącej się. Odniesienie się do (własnej) starości, rozwijane przez całe życie, jest istotnym składnikiem dojrzałej tożsamości jednostki.

Starość jest końcowym etapem życia, ale i wynikiem wcześniejszych doświadczeń życiowych. Świadomość tych doświadczeń i ich edukacyjnych oddziaływań jest istotnym, choć nie jedynym elementem tworzącym pomyślną starość. Głównym składnikiem pomyślnej starości jest akceptacja siebie i swego losu, kształtowana permanentnie przez całe życie, będąca wynikiem dojrzałej afirmacji ŻYCIA. Pomyślna starość jest ponadto sztuką, którą nabywa się przez całe życie. Pomyślna starość wynika najczęściej z pomyślnego dotychczasowego życia. Starości uczymy się żyjąc. Mamy wiele lat, by nauczyć się dobrze żyć w starości. W tym kontekście, starość nie powinna nas zaskoczyć.

Radzenie sobie ze starością to przede wszystkim radzenie sobie ze starością „od środka” - to samoradzenie. To uruchomienie czynników motywujących do zachowań twórczych, transgresyjnych. Starość to zadanie rozwojowe i szansa dalszego dojrzewania. To wynik procesu samorozwoju, którego nikt nie może za jednostkę wykonać, a który może cieszyć swym efektem.

Starość bywa dziś coraz częściej określana jako wyzwanie dla współczesnych społeczeństw i jednostek. Wyzwania jednak najczęściej obciążają, są pewnym brzemieniem i balastem. Warto spojrzeć na starość inaczej - jako na rezerwuar pozytywnych wartości, tak dla społeczeństwa, jak i dla poszczególnych jednostek. I niewątpliwie można i trzeba takich wartości doszukiwać się w starości, choćby „odkurzając” wartości dostrzegane we wcześniejszych kulturach. Starość nie musi oznaczać „złego przeznaczenia społecznego", lecz może być doświadczana jako kolejny naturalny etap życia i rozwoju człowieka. W tym kontekście proces starzenia się człowieka może być procesem osobowego dojrzewania, który zarazem wzbogaca i życie wspólnotowe. 


\section{Bibliografia}

Aleksander T. (2002), Andragogika, Ostrowiec Świętokrzyski.

Borsowa I. (red.), (1986), Encyklopedia seniora, Warszawa.

Brzezińska A. I. (red.) (2005), Psychologiczne portrety człowieka, Praktyczna psychologia rozwojowa, Gdańskie Wydawnictwo Psychologiczne, Gdańsk.

Dubas E. (1990), Potrzeby edukacji dorostych - pojęcie i kategoryzacja, „Oświata Dorosłych", nr 6, s. 208-213.

Dubas E. (2000), Edukacja dorosłych w sytuacji samotności i osamotnienia, Wydawnictwo Uniwersytetu Łódzkiego, Łódź.

Dubas E., (2002), Drogi rozwojowe starości, „Zeszyty Naukowe WSHE w Łodzi”, nr 7/27, s. 15-22.

Dubas E. (2004), Starość w perspektywie rozwoju, duchowości i edukacji. Geragogiczny przyczynek do refleksji nad starością i starzeniem się człowieka [w:] E. A. Wesołowska (red.), Człowiek i edukacja, Wydawnictwo Naukowe NOVUM, Płock, s. $131-157$.

Dubas E. (2008), Edukacyjny paradygmat badawczy w geragogice [w:] Kuchcińska M. (red.) Edukacja do i w starości, Wydawnictwo Kujawsko-Pomorskiej Szkoły Wyższej, Bydgoszcz, s. 43-65.

Dubas E. (2012), Sztuka starzenia się - uczenie się starości. Kontekst andragogiczny, „Biblioteka Gerontologii Społecznej”, nr 1, s. 11-29.

Halicki J. (2004), Społeczne teorie starzenia się [w:] Halicka M., Halicki J. (red.), Zostawić ślad na ziemi, Wydawnictwo Uniwersytetu w Białymstoku, Białystok.

Halicki J. (2010), Obrazy starości rysowane przeżyciami seniorów, Wydawnictwo Uniwersytetu W Białymstoku, Białystok.

Hill R.D. (2009), Pozytywne starzenie się, Laurum, Warszawa.

Kamiński A. (1978), Wychowanie do starości jako czynnik adaptacji ludzi starszych do nowoczesnego środowiska [w:] Kamiński A., Studia i szkice pedagogiczne, Państwowe Wydawnictwo Naukowe PWN, Warszawa.

McCrae R.R., Costa P.T. Jr. (2005), Osobowość dorosłego człowieka, Wydawnictwo WAM, Kraków.

Mead M. (2000), Kultura i tożsamość Studium dystansu międzypokoleniowego, Warszawa.

Mosakowska M., Więcek A., Błędowski P. (red.), (2012), Aspekty medyczne, psychologiczne, socjologiczne i ekonomiczne starzenia się ludzi w Polsce, Termedia Wydawnictwo Medyczne, Poznań.

Nowocień J., Zuchora K. (red.) (2012), Aktywność fizyczna i społeczna osób trzeciego wieku, Warszawa.

Pietrasiński Z. (1988), Rozwój myślenia i osobowości dorosłych, „Oświata Dorosłych”, nr 7, s.385-391.

Piotrowski J. (1973), Miejsce człowieka starego w rodzinie i społeczeństwie, Wydawnictwo Naukowe PWN, Warszawa. 


\section{2 | Elżbieta Dubas}

Piotrowski J. (red.), (1975), Starzenie się i starość w badaniach gerontologicznych w Polsce. Pamiętnik I Zjazdu Naukowego Polskiego Towarzystwa Gerontologicznego Warszawa 2-3.12.1974, Warszawa-Wrocław.

Staręga-Piasek J. (2006), O niektórych mitach wokół ludzi starych i starości [w:] Halicka M., Halicki.

J. (red.), Zostawić ślad na ziemi, Wydawnictwo Uniwersytetu w Białymstoku, Białystok.

Synak B. (red.), (2002), Polska starość, Wydawnictwo Uniwersytetu Gdańskiego, Gdańsk.

Szatur-Jaworska B., Błędowski P., Dzięgielewska M. (2006), Podstawy gerontologii społecznej, Oficyna Wydawnicza ASPRA-JR, Warszawa.

Zych A. A. (2001), Słownik gerontologii społecznej, Wydawnictwo Akademickie „Żak”, Warszawa.

Zych A. A. (2007), Leksykon gerontologii, Oficyna Wydawnicza „Impuls”, Kraków. 